\title{
Perbedaan Tingkat Keterbukaan Diri Berdasarkan Konteks Budaya dan Jenis Hubungan
}

\author{
Reyandra Dio Boentoro', Endah Murwani² \\ ${ }^{1.2}$ Universitas Multimedia Nusantara \\ Jl. Scientia Boulevard, Serpong, Tangerang Selatan - Indonesia \\ ${ }^{1}$ reyandradb@gmail.com,2endahmurwani@umn.ac.id
}

\begin{abstract}
Self-disclosure as communication behaviour, plays an important role in relationship development. Unequal level of self-disclosure between individuals causes relationship development to be stagnant and even deteriorate. Therefore, any factors that affect level of self-disclosure are need to be known. This research examines wheter the level of self-disclosure would differ between cultural context and types of relationship. This research uses Social Penetration Theory which explains about self- disclosure in relationships development. Research method which have been used is survey. Data collection is done with questionnaire deployment to 60 respondents (30 respondents with Javanese's cultural background and 30 respondents with Bataknese's cultural background). Data is analyzed using ANOVA to compare level of self-disclosure among different context of cultures and types of relationships. The result supports three hypotheses, (a) there is difference in level of self-disclosure between different cultural context. The difference is caused by different perspective of communication in these cultures. (b) there is difference in level of self-disclosure between different type of relationships which caused by nature of each relationship that determines amount of information to disclose. (c) there is interaction between context of culture and types of relationships in affecting level of self-disclosure. The interaction is caused by different views about nature of each relationship in each culture.
\end{abstract}

Key words: Self-disclosure, Cultural Context, Romantic Relationships, Friendship Relationships

\begin{abstract}
Abstrak
Keterbukaan diri sebagai perilaku komunikasi, berperan dalam pengembangan hubungan seseorang. Ketidakseimbangan tingkat keterbukaan diri antarpribadi yang berhubungan dapat menyebabkan situasi dan keintiman hubungan yang buruk. Oleh sebab itu perlu dipahami hal-hal yang menyebabkan tingkat keterbukaan diri seseorang. Penelitian ini melihat ada atau tidaknya perbedaan tingkat keterbukaan diri berdasarkan konteks budaya dan jenis hubungan. Teori yang diacu adalah Teori Penetrasi Sosial yang menjelaskan mengenai keterbukaan diri dalam suatu hubungan. Metode penelitian yang dipakai adalah survei. Pengumpulan data dilakukan melalui penyebaran kuisioner kepada 60 responden (30 responden berbudaya Jawa dan 30 responden berbudaya Batak). Data dianalisis dengan ANOVA untuk membandingkan keterbukaan diri antara konteks budaya dan jenis hubungan. Hasil penelitian membuktikan tiga hipotesis yaitu (a) ada perbedaan tingkat keterbukaan diri berdasarkan konteks budaya. (b) ada perbedaan tingkat keterbukaan diri berdasarkan jenis hubungan. (c) ada interaksi antara konteks budaya dan jenis hubungan dalam memengaruhi tingkat keterbukaan diri.
\end{abstract}

Kata kunci: Keterbukaan diri, Konteks budaya, Hubungan romantis, Hubungan persahabatan

Copyright $@ 2018$ Ikatan Sarjana Komunikasi Indonesia. All rights reserved

\section{PENDAHULUAN}

Keterampilan sosial menunjang keberhasilan individu dalam membina dan mengembangkan hubungan. Melalui keterampilan sosial, individu memenuhi syarat tercapainya penyesuaian sosial yang baik dalam kehidupan sehingga dapat memenuhi kebutuhan untuk berinteraksi dan berhubungan dengan 
sesamanya. Salah satu aspek yang penting dalam keterampilan sosial tersebut adalah keterbukaan diri (self disclosure).

Keterbukaan diri merupakan topik kajian yang populer dalam ilmu psikologi dan komunikasi interpersonal. Cramer dan Tschann melakukan penelitian keterbukaan diri dalam hubungan romantis dan persahabatan (Kito, 2005, h. 128). Sedangkan Dolgin, Meyer, \& Schwartz melakukan penelitian keterbukaan diri dalam hubungan persahabatan lintas-seks (Kito, 2005: 131).

Penelitian yang dilakukan Johnson (1981) menunjukkan bahwa individu yang mampu memahami keterbukaan diri (self disclosure) akan dapat mengungkapkan diri secara tepat. Mereka terbukti mampu menyesuaikan diri (adaptive), lebih percaya diri sendiri, lebih kompeten, dapat diandalkan, lebih mampu bersikap positif, percaya terhadap orang lain, lebih objektif, dan terbuka dalam suatu hubungan. Dengan memahami kesediaan seseorang untuk membuka diri, pengembangan hubungan dapat berlangsung dengan baik.

Namun, seringkali seseorang mengasumsikan tingkat keterbukaan diri setiap orang itu kurang lebih sama, sehingga ia akan terbuka pada tingkatan yang sama kepada setiap orang, dan mengharapkan keterbukaan balasan pada tingkatan yang sama pula. Padahal tidak selalu demikian. Ada banyak hal yang menyebabkan tingkat keterbukaan diri seseorang kepada orang lain berbeda satu dengan yang lainnya. Akibat kurangnya pemahaman terhadap keterbukaan diri tersebut, terjadi kesenjangan ekspektasi perilaku keterbukaan diri dari satu orang dengan yang lain. Individu tidak mendapatkan keterbukaan balasan yang sesuai dengan yang ia harapkan dan hubungan justru akan mengalami kemunduran.

Oleh sebab itu, menjadi penting untuk memahami dan membuktikan ada atau tidaknya perbedaan tingkat keterbukaan diri di setiap hubungan pada setiap orang. Dengan memahami hal tersebut, seseorang memiliki pemahaman untuk menyesuaikan perilaku keterbukaannya dengan lawan interaksinya sehingga terjadi pengembangan keintiman hubungan yang baik dan harmonis.

Pemahaman keterbukaan diri secara konseptual mengatakan bahwa hal yang mempengaruhi sejauh mana kesediaan seseorang membuka dirinya adalah value individu tersebut. Budaya, sebagai aspek yang membentuk worldview dan value seseorang, diasumsikan mempengaruhi keterbukaan diri, sehingga apabila sesuai dengan pemahaman teoretis tersebut, dalam budaya yang berbeda, tingkat keterbukaan diri-nya juga berbeda.

Indonesia merupakan negara plural, terdiri dari banyak suku bangsa dan budaya. Jika teori tersebut relevan, berarti beragam pula tingkat keterbukaan diri pada masyarakat Indonesia. Dalam kemajemukan budaya di Indonesia, ada stereotip terhadap sejumlah budaya yang dipertentangkan karakteristiknya. Salah satunya adalah budaya Jawa dan budaya Batak, yang memiliki karakteristik masyarakat yang bertolak belakang. Mulder (Eman, 2004), mengatakan bahwa orang Jawa berusaha untuk menampilkan diri sebagai orang yang halus dan sopan, tetapi tertutup atau tidak mau terbuka kepada orang lain. Pada budaya Batak, berdasarkan penelitian oleh Warnaen (Eman, 2004), tentang stereotip karakter masyarakat Batak dari sukusuku lain di Indonesia adalah, orang yang emosional, kasar, cepat marah, memiliki keterikatan keluarga yang kuat, senang berkelompok, agresif, kepala batu, licik, ribut, berkata dengan apa adanya, ambisius, dan terbuka. Budaya Jawa dan budaya Batak juga menjadi representasi dari budaya konteks tinggi dan budaya konteks rendah dalam penelitian Loisa (1996: 25) mengenai konteks kebudayaan. Dari fenomena tersebut, penelitian ini berupaya mengungkapkan apakah perbedaan nilai dari kedua budaya tersebut mengakibatkan adanya perbedaan tingkat keterbukaan diri di antara masyarakatnya.

Setiap orang pasti menjalani banyak hubungan dalam hidupnya. Hubungan-hubungan tersebut memiliki peranan dalam membentuk diri seseorang. Bagi mahasiswa, yang umumnya merupakan kelompok dewasa muda, mereka menghadapi situasi sosial yang berbeda dari sebelumnya. Mereka dituntut mandiri dan lepas dari sosok orang tua dan keluarga. Mereka telah dipandang sebagai individu secara utuh dan memiliki kewenangan secara penuh terhadap dirinya sendiri. Sebagai mahasiswa, individu akan mengalami sosialisasi sekunder, yaitu pembentukan kepribadian melalui interaksi dengan orang disekitarnya ketika orang secara dewasa terjun ke masyarakat. Pada tahapan ini, hubungan dengan sesama dan sejawat lebih berpengaruh dalam 
membangun kepribadian daripada hubungan dengan keluarga. Mereka berinteraksi dan membangun hubungan dengan banyak orang. Di antara banyak hubungan tersebut yang memberikan pengaruh signifikan adalah hubungan romantis, hubungan dengan orang lain berdasarkan perasaan cinta untuk pemenuhan hasrat dan menjadi pendamping hidup, serta hubungan persahabatan, hubungan yang didasari kepercayaan dan stabilitas untuk memenuhi kebutuhan sosial. Dengan karakteristik hubungan yang beragam, individu diasumsikan tidak seharusnya membuka diri secara sama ke setiap hubungan yang dimilikinya.

Dengan mengetahui ada-tidaknya perbedaan tingkat keterbukaan diri dalam hubungan-hubungan yang berbeda, seseorang mampu menyesuaikan tingkat keterbukaan diri sesuai hubungan yang dimilikinya dengan lawan interaksinya sehingga menghindari terjadinya kesenjangan komunikasi dan kemunduran pengembangan hubungan akibat ketidaksetaraan tingkat keterbukaan diri.

Setelah melihat dan mengetahui apakah konteks budaya dan jenis hubungan mempengaruhi keterbukaan diri, perlu dipahami pula apakah faktor-faktor tersebut memiliki keterkaitan atau interaksi dalam mempengaruhi keterbukaan diri. Hal ini diperuntukkan untuk dapat lebih memahami lagi pemetaan tingkat keterbukaan diri dalam hubungan-hubungan berbeda pada konteks budaya yang berbeda pula. Dengan pemahaman yang lebih baik, maka akan semakin efektif pula komunikasi yang dilakukan untuk pengembangan hubungan secara lancar.

Dengan latar belakang fenomena dan pemikiran tersebut, penulis memfokuskan penelitian terhadap perbedaan tingkat keterbukaan diri pada kelompok konteks budaya, dan tipe hubungan yang berbeda. Penelitian ini akan memeriksa keterbukaan diri di empat tipe hubungan yang berbeda, yaitu passionate love relationship, companionate love relationship, same-sex friendship (persahabatan sesama jenis), dan cross-sex relationship (persahabatan lintas-seks) dalam dua konteks budaya: budaya Jawa (represensasi budaya highcontext) dan budaya Batak (represensasi budaya low-context). Pengujian ini dilakukan untuk membuktikan kebenaran pemahaman bahwa keterbukaan diri terkait dengan aspek konteks budaya dan tipe hubungan. Hasil dari penelitian diharapkan mampu memberikan gambaran terhadap tingkat keterbukaan diri berdasarkan konteks budaya dan hubungan untuk memberikan panduan bersikap dan tingkat kewajaran dalam membuka diri supaya individu dapat beradaptasi secara sesuai dalam berhubungan dengan orang lain.

Tujuan penelitian untuk (1) mengetahui ada atau tidaknya perbedaan tingkat keterbukaan diri berdasarkan konteks budaya. (2) mengetahui ada atau tidaknya perbedaan tingkat keterbukaan diri berdasarkan jenis hubungan. (3) mengetahui ada atau tidaknya interaksi antara konteks budaya dan jenis hubungan dalam mempengaruhi tingkat keterbukaan diri.

\section{KERANGKA TEORI}

Teori Penetrasi Sosial mengidentifikasikan proses meningkatnya kedekatan dan keintiman hubungan. Keterbukaan diri menjadi konsep yang penting dalam teori ini, dan menjadi tema utama pengembangan teori penetrasi sosial. Proses penetrasi dilihat dari luas (breadth) dan dalam (depth). Konsep breadth yaitu mengenali orang lain dari banyaknya jenis informasi yang berbeda mengenai orang tersebut, sedangkan konsep depth yaitu mengenal dengan mengetahui secara mendetil mengenai satu atau dua hal. Seiring dengan hubungan antara dua individu berkembang, mereka berbagi aspek lebih banyak tentang diri mereka, menambah breadth dan depth dari yang mereka ketahui. Keberhasilan penetrasi ditentukan oleh keterbukaan diri dari individu terhadap pasangannya.

Altman dan Taylor mengidentifikasikan empat langkah dalam perkembangan hubungan (Littlejohn dan Foss, 2008: 203) yaitu: (1) Orientation, meliputi komunikasi impersonal yang hanya membuka diri mengenai informasi yang bersifat sangat umum. Jika tahapan ini menguntungkan bagi partisipan yang terlibat, maka berlanjut ke tahapan berikutnya; (2) Exploratory Affective Change, hubungan bergerak ke tingkat keterbukaan diri yang lebih dalam; (3) Affective Exchange, berfokus kepada perasaan untuk mengevaluasi dan meninjau kembali dalam tingkatan yang sudah dalam. Tahapan ini hanya dapat dicapai apabila hubungan dirasa menguntungkan pada tahapan sebelumnya. (4) Stable Exchange, yaitu tahapan dengan keintiman yang sangat tinggi. 
Dari deskripsi Teori Penetrasi Sosial dapat disimpulkan hipotesis dan asumsi yang diambil secara teoretis. Pertama, Teori Penetrasi Sosial mengasumsikan bahwa hubungan dapat diprediksi. Hubungan dapat berkembang ke arah yang lebih jauh dengan adanya keterbukaan diri dan mengakibatkan perubahan pada proses komunikasi. Dengan adanya keterbukaan, maka semakin mudah terjadinya penetrasi oleh individu lain, secara mendalam (depth) dan meluas (breadth).

Kedua, keterbukaan diri bersifat resiprokal, dalam hubungan antara dua orang, diperlukan tingkat keterbukaan yang setara. Dengan kesetaraan secara emosional dalam hal keterbukaan, keterbukaan diri dari satu orang akan membawa kepada keterbukaan diri dari orang lain (Griffin, 2012: 116).

Ketiga, apabila hubungan dirasa menguntungkan (reward lebih besar dari cost), maka hubungan akan berkembang semakin jauh, tetapi apabila dirasa merugikan (cost lebih besar dan tidak sebanding dengan reward), maka hubungan tidak akan berkembang (Littlejohn dan Foss, 2008: 203).

Sementara itu Keterbukaan diri adalah kesediaan untuk membagi pengalaman pribadi, perasaan, nilainilai diri, sikap, kepercayaan, rahasia pribadi, dan lain-lain kepada orang lain secara jujur dan transparan (Griffin, 2012: 115).

Keterbukaan diri memerankan peranan penting dalam komunikasi antarpribadi karena keterbukaan diri membuat orang saling mengenal satu sama lain. Keterbukaan diri terjadi pada hubungan dyadic (dua orang) untuk menjaga keamanan informasi personal.

West dan Turner (2006: 228) mengungkap beberapa prinsip utama dalam keterbukaan diri: Pertama, keterbukaan diri terjadi atas sesuatu yang penting pada beberapa interaksi. Prinsip ini menjelaskan bahwa individu cenderung untuk melakukan percakapan ringan dan superfisial. Perilaku keterbukaan diri jarang dilakukan dalam beragamnya rutinitas yang menuntut untuk melakukan komunikasi seadanya saja. Namun, ada saat tertentu bagi seseorang untuk membuka diri dan bercerita kepada sahabat atau orang dekatnya.

Kedua, keterbukaan diri terjadi di antara dua orang yang memiliki hubungan dekat atau intim. Jumlah dan frekuensi informasi yang diberikan dalam keterbukaan diri bergantung pada bagian utama dalam hubungan individu dengan orang lain, seperti pernikahan, keluarga, dan persahabatan. Alasan seseorang bercerita mengenai informasi yang bersifat pribadi adalah karena adanya perasaan aman dan nyaman dalam hubungan yang terjalin dengan orang tersebut.

Ketiga, keterbukaan diri merupakan sebuah proses timbal balik. Keterbukaan diri sebagai perilaku dalam hubungan dyadic akan menghasilkan efek timbal-balik berupa keterbukaan oleh anggota yang lain.

Keempat, keterbukaan diri terjadi dalam konteks waktu. Keterbukaan diri terjadi secara bertahap seiring dengan berjalannya waktu. Hal yang biasanya diceritakan kepada orang lain dimulai dari hal yang dangkal dan superfisial. Tingkat keintiman dan kedalaman hal yang diceritakan meningkat seiring berjalannya waktu dan hubungan dengan teman tersebut berlanjut semakin dalam. Fungsi dan makna keterbukaan bervariasi seiring dengan berjalannya waktu.

Informasi dalam keterbukaan diri bersifat deskriptif dan evaluatif. Deskriptif artinya individu melukiskan berbagai fakta mengenai diri sendiri yang mungkin untuk diketahui orang lain seperti pekerjaan, alamat, dan usia. Evaluatif artinya individu mengemukakan pendapat atau perasaan pribadinya lebih mendalam kepada tahap pengungkapan hal-hal yang disukai atau tidak disukai.

Kedalaman dalam keterbukaan diri tergantung pada situasi dan orang yang diajak untuk berinteraksi. Situasi yang menyenangkan dan perasaan aman dapat mendorong seseorang untuk lebih mudah membuka diri. Selain itu adanya rasa percaya dan timbal balik dari lawan bicara menimbulkan kecenderungan untuk memberikan reaksi yang sepadan. Latar belakang kebudayaan juga memiliki pengaruh dalam keterbukaan diri seseorang. Tiap-tiap bangsa dengan latar belakang budaya masing-masing memiliki batas tertentu sampai sejauh mana individu pantas atau tidak pantas mengungkapkan diri.

Richard West, dalam bukunya (2009: 194) menyebutkan beberapa faktor yang dapat memengaruhi keputusan seseorang untuk membuka diri, yaitu: (1) siapa dirinya, (2) kebudayaannya, (3) gender, (4) siapa pendengarnya, dan (5) topik. Dalam membuka diri, diperlukan adanya beberapa petunjuk agar seseorang dapat memutuskan untuk membuka diri, cara membuka diri, merespon keterbukaan diri, dan menghindari tekanan 
yang diakibatkan oleh keterbukaan diri. Keterbukaan diri pada umumnya terjadi ketika iklim komunikasi menegaskan, menerima, dan mendukung (Wood, 2008: 193).

Julia T. Wood berpendapat (2007: 63) bahwa keterbukaan diri merupakan cara paling penting bagi seseorang untuk dapat mempelajari diri sendiri. Seiring dengan dibukanya informasi diri mengenai harapan, ketakutan, mimpi, dan perasaan, akan diperoleh respon dari orang lain yang memberikan perspektif baru pada diri sendiri. Keterbukaan diri juga menjadi perilaku komunikasi yang digunakan untuk mengurangi ketidakpastian dalam hubungan. Melalui membagi informasi pribadi tentang diri sendiri, diharapkan adanya respon terhadap perilaku keterbukaan yang dilakukan. Selain itu juga dengan membuka diri, ada harapan untuk mendapatkan perilaku terbuka balasan dari orang lain (Wood, 2008: 194).

Akan tetapi, meskipun memiliki sejumlah potensi positif dalam hubungan, keterbukaan diri memiliki risiko. Wood (2008: 203) mengungkapkan risiko-risiko keterbukaan diri yang ditemukan dalam penelitian komunikasi adalah adanya kemungkinan penolakan dan pandangan remeh terhadap individu yang membuka diri dari orang lain. Informasi pribadi yang dibagikan dapat digunakan untuk melawan diri sendiri dan kemungkinan untuk kehilangan kekuatan karena telah membuka mengenai kelemahan diri. Risiko-risiko ini dapat terhindari dengan membuka diri secara hati-hati.

Keterbukaan diri memiliki fungsi atau tujuan yang berbeda pada sebuah hubungan. Dua fungsi tujuan sosial adalah validasi sosial dan kontrol sosial. Validasi sosial yaitu jika feedback yang diterima seseorang setelah ia membuka dirinya dapat memecahkan masalah atau membantunya berpikir lebih jauh lagi. Kontrol sosial yaitu jika informasi yang diberikan seseorang saat ia membuka dirinya memberikan citra yang baik sehingga orang lain merasa terkesan dan bersedia mendengarkan nasihat atau opininya. Selain tujuan sosial tersebut, keterbukaan diri juga memiliki fungsi personal. Fungsi personal tersebut diwujudkan dalam mengungkapkan informasi yang bersifat pribadi, sehingga menjadi wajar terjadi komunikasi resiprokal dengan penerima ungkapan yang bersifat pribadi. Diharapkan penerima ungkapan tersebut mengungkapkan balik informasi yang bersifat pribadi baginya, atau paling tidak bersifat empatik.

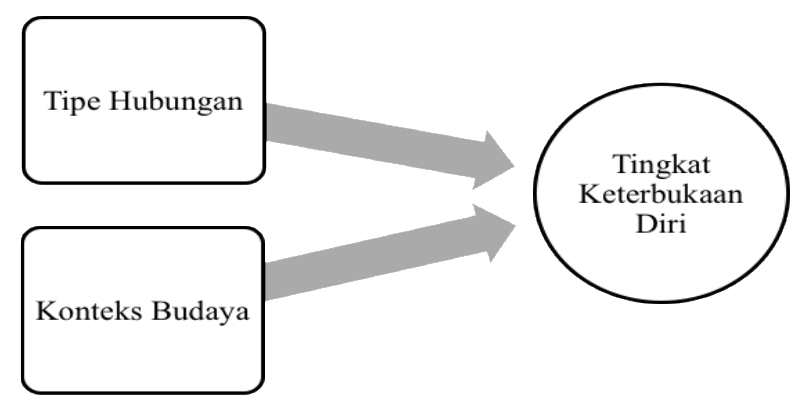

\section{METODE PENELITIAN}

Penelitian ini bersifat eksplanatif yang menjelaskan mengenai konteks budaya dengan tingkat keterbukaan diri. Metode yang digunakan adalah survei, dengan populasi mahasiswa Universitas Multimedia Nusantara yang berlatar belakang budaya Batak atau Jawa. Untuk menjaring populasi sesuai kriteria tersebut dilakukan dengan menggunakan kuesioner filter. Populasi sasaran berjumlah 200 mahasiwa, 170 mahasiswa berlatar budaya Jawa dan 30 mahasiswa berlatar budaya Batak. Teknik pengambilan sampel menggunakan stratified random sampling non proporsional., dengan mengambil 30 responden berlatar belakang budaya Batak, dan 30 responden berlatar belakang budaya Jawa.

Dalam penelitian ini, pengukuran tingkat keterbukaan diri mengacu pada instrumen pengukuran klasik dari The Jourard Sixty-Item Self-Disclosure Questionnaire (Jourard, 1958) dengan dimensi konsep attitude/opinion, taste and interest, work/study, money, personality, dan body. Untuk dimensi opini mencakup 5 indikator, dimensi minat terdiri dari 5 indikator, dimensi aktifitas perkuliahan mencakup 2 indikator, dimensi 
keuangan terdiri dari 3 indikator, dimensi kepribadian mencakup 4 indikator dan dimensi fisik mencakup 3 indikator.

Uji validitas instrumen dilakukan dengan factor analysis. Hasil pengujian menunjukan instrumen penelitian valid dengan nilai KMO sebesar 0,871. Nilai anti-image correlation dari setiap item juga tidak ada yang lebih rendah dari 0,6. Sedangkan uji reliabilitas dilakukan dengan reliability analysis. Hasil pengujian menunjukan indikator-indikator reliabel dengan nilai dari Cronbach's alpha $(\alpha)$ sebesar 0,907.

Data dianalisis dengan Analysis of Varians (ANOVA) untuk melihat perbedaan dan membandingkan beberapa kelompok variabel yang diukur dengan satu atau lebih faktor. Hipotesis penelitian adalah sebagai berikut :

H01: $\alpha 1=\alpha 2$ (Tidak ada perbedaan yang signifikan dalam tingkat keterbukaan diri berdasarkan konteks budaya)

Ha1: $\alpha 1 \neq \alpha 2$ (Ada perbedaan yang signifikan dalam tingkat keterbukaan diri berdasarkan konteks budaya)

H02: $\beta 1=\beta 2=\beta 3$ (Tidak ada perbedaan yang signifikan dalam tingkat keterbukaan diri berdasarkan jenis hubungan)

$\mathrm{Ha} 2: \beta 1 \neq \beta 2 \neq \beta 3$ (Ada perbedaan yang signifikan dalam tingkat keterbukaan diri berdasarkan jenis hubungan)

H03: $(\alpha \beta) 11=(\alpha \beta) 12=(\alpha \beta) 13=(\alpha \beta) 21=(\alpha \beta) 22=(\alpha \beta) 23$ (Tidak ada interaksi antara konteks budaya dengan jenis kelamin dalam hal tingkat keterbukaan diri)

Ha3: $(\alpha \beta) 11 \neq(\alpha \beta) 12 \neq(\alpha \beta) 13 \neq(\alpha \beta) 21 \neq(\alpha \beta) 22 \neq(\alpha \beta) 23$ (Ada interaksi antara konteks budaya dengan jenis kelamin dalam hal tingkat keterbukaan diri)

\section{HASIL PENELITIAN}

Uji Hipotesis dalam penelitian ini menggunakan analisis Two-way ANOVA untuk membandingkan perbedaan rata-rata antara kelompok yang telah dibagi dalam dua variabel independen. Tujuan utama dari analisis Two-way ANOVA ini adalah untuk memahami jika ada interaksi antara dua variabel independen terhadap variabel dependen.

Dalam penelitian ini, dua variabel independen adalah konteks budaya dan jenis hubungan, sedangkan variabel dependennya adalah keterbukaan diri, sehingga Two-way ANOVA 2x3 dilakukan untuk menguji pengaruh konteks budaya (Jawa dan Batak) serta jenis hubungan (Romantic Relationship, Same-sex Friendship, dan Cross-sex Friendship) terhadap tingkat keterbukaan diri.

Hasil pengujian hipotesis terlihat pada table berikut :

Tabel 1

Tests of Between-Subjects Effects

\begin{tabular}{|c|c|c|c|c|c|}
\hline Source & $\begin{array}{c}\text { Type III Sum } \\
\text { of Squares }\end{array}$ & $\mathrm{df}$ & Mean Square & $\mathrm{F}$ & Sig. \\
\hline Corrected Model & $9582.711^{\mathrm{a}}$ & 5 & 1916.542 & 10.551 & .000 \\
\hline Intercept & 500755.756 & 1 & 500755.756 & 2756.843 & .000 \\
\hline culture & 1692.800 & 1 & 1692.800 & 9.319 & .003 \\
\hline relationship type & 6469.011 & 2 & 3234.506 & 17.807 & .000 \\
\hline $\begin{array}{l}\text { culture * } \\
\text { relationship type }\end{array}$ & 1420.900 & 2 & 710.450 & 3.911 & .022 \\
\hline Error & 31605.533 & 174 & 181.641 & & \\
\hline Total & 541944.000 & 180 & & & \\
\hline Corrected Total & 41188.244 & 179 & & & \\
\hline
\end{tabular}

Hasil uji hipotesis penelitian pertama menunjukkan bahwa ada perbedaan yang signifikan dalam tingkat keterbukaan diri berdasarkan konteks budaya. Nilai signifikansi pada baris konteks budaya (culture) pada tabel 
1. yaitu $p=0,003$ yang berarti lebih kecil dari nilai alpha $(p<0,05)$. Dengan demikian H01 ditolak, artinya ada perbedaan keterbukaan diri berdasarkan konteks budaya

Bila dicermati tabel 2, nilai mean dari kelompok sampel budaya yang diujikan, hasil analisis menunjukkan rata-rata keterbukaan diri budaya Batak $(\mathrm{M}=55,811 ; \mathrm{SD}=1,421)$, lebih tinggi daripada nilai rata-rata keterbukaan diri budaya Jawa $\mathrm{h}(\mathrm{M}=49,678 ; \mathrm{SD}=1,421)$.

Tabel 2

Mean Konteks Budaya

Dependent Variable: Self Disclosure

\begin{tabular}{|l|r|r|r|r|}
\hline \multirow{2}{*}{ Budaya } & & & \multicolumn{2}{|c|}{$95 \%$ Confidence Interval } \\
\cline { 4 - 5 } & Mean & Std. Error & Lower Bound & Upper Bound \\
\hline Batak & 55.811 & 1.421 & 53.007 & 58.615 \\
Jawa & 49.678 & 1.421 & 46.874 & 52.482 \\
\hline
\end{tabular}

Hasil perbandingan nilai rata-rata tersebut menunjukkan bahwa budaya Jawa sebagai representasi budaya berkonteks tinggi memiliki tingkat keterbukaan diri yang lebih rendah daripada budaya Batak sebagai representasi budaya berkonteks rendah. Hal tersebut dikarenakan budaya Jawa merupakan budaya yang lebih implisit daripada budaya Batak dan mereka berbicara lebih sedikit mengenai diri mereka sendiri daripada yang dilakukan oleh budaya Batak.

Budaya berkonteks tinggi memiliki banyak konteks yang mengelilingi pesan yang tersampaikan, oleh sebab itu mereka tidak banyak mengungkapkan tentang diri mereka sendiri tetapi mengharapkan orang lain memahami suasana hati yang tidak terucapkan, dan isyarat-isyarat atau konteks yang ada. Selain itu, karena budaya komunikasi mereka yang sensitif, mereka cenderung sensitif pula terhadap perasaan orang lain. Karena mereka berusaha untuk menjaga harmoni dalam kelompok dan hubungan, mereka mungkin berpikir bahwa membicarakan mengenai isu personal mereka dapat meruntuhkan harmoni dan melukai perasaan orang-orang di sekitar mereka.

Di sisi lain, budaya berkonteks tinggi seperti budaya Batak, mementingkan ekspresi diri, sehingga mereka berupaya untuk mengekspresikan diri. Budaya berkonteks tinggi tidak memiliki banyak konteks yang menyertai pesan mereka, sehingga mereka mengungkapkan yang mereka ingin ungkapkan. Mereka juga memiliki tafsiran diri independen dan mencoba untuk menemukan yang cara terbaik untuk mengekspresikan atribut mereka yang unik (Markus dan Kitayama, 1991: 226).

Hasil pengujian hipotesis kedua, memperlihatkan bahwa ada perbedaan tingkat keterbukaan diri yang signifikan di antara jenis-jenis hubungan yang diteliti. Nilai signifikansi pada tabel 1 adalah $p=0,000$. Nilai tersebut menunjukkan nilai yang lebih kecil dari nilai alpha $(p<0,05)$. Dengan demikian, dapat ditentukan bahwa H02 juga ditolak yang berarti ada perbedaan keterbukaan diri berdasarkan jenis hubungan.

Tabel 3 di bawah ini menunjukkan nilai mean keterbukaan diri dari masing-masing jenis hubungan. Nilai keterbukaan yang paling tinggi ada pada jenis hubungan romantis $(\mathrm{M}=58,35$; $\mathrm{SD}=1,74)$, kemudian hubungan pertemanan berjenis kelamin sama $(M=55,45 ; \mathrm{SD}=1,74)$, dan yang paling kecil adalah pertemanan berbeda jenis kelamin $(M=44,433 ; \mathrm{SD}=1,74)$.

Tabel 3

Mean Jenis Hubungan

Dependent Variable: Self Disclosure

\begin{tabular}{|l|r|r|r|r|}
\hline & & & \multicolumn{2}{|c|}{$95 \%$ Confidence Interval } \\
\cline { 4 - 5 } Jenis Hubungan & Mean & Std. Error & Lower Bound & Upper Bound \\
\hline Romantic Relationship & 58.350 & 1.740 & 54.916 & 61.784 \\
Same-sex Friendship & 55.450 & 1.740 & 52.016 & 58.884 \\
Cross-sex Frienship & 44.433 & 1.740 & 40.999 & 47.867 \\
\hline
\end{tabular}


Dari hasil perbandingan nilai rata-rata yang tertera pada tabel 3 , terlihat bahwa pada hubungan romantis, tingkat keterbukaan diri lebih tinggi daripada jenis hubungan lain yang diteliti, kemudian disusul oleh hubungan persahabatan berjenis kelamin sama, lalu hubungan persahabatan berbeda jenis kelamin.

Dalam budaya Jawa maupun Batak memiliki tingkat keterbukaan diri yang lebih tinggi pada hubungan pertemanan berjenis kelamin sama daripada berjenis kelamin berbeda. Hasil ini dikarenakan adanya lebih banyak kesamaan antara orang yang memiliki jenis kelamin sama sehingga kesamaan pengalaman yang mereka miliki lebih banyak daripada orang yang berbeda jenis kelamin. Memungkinkan pula adanya keraguan dari seseorang untuk mengungkapkan aspek negatif dari diri mereka sendiri kepada orang lain yang berjenis kelamin berbeda dengan mereka karena adanya harapan dan kemungkinan untuk terbangunnya hubungan romantis dengan orang tersebut. Mengungkapkan informasi diri yang bersifat negatif memungkinkan untuk mengecilkan kemungkinan tersebut.

Penjelasan lainnya dapat diambil dari penelitian Bleske dan Buss (2001: 1313-1315). Penelitian tersebut melihat alasan seseorang untuk menginisiasi persahabatan berbeda jenis kelamin. Hasil yang didapatkan menunjukkan bahwa bagi pria, daya tarik seksual dan keinginan terhadap seks menjadi alasan penting untuk memulai persahabatan sedangkan bagi perempuan, perlindungan fisik menjadi alasan yang utama. Alasan-alasan untuk memiliki hubungan persahabatan berbeda jenis kelamin tersebut tidak berkaitan banyak dengan keterbukaan diri. Hal ini menjelaskan partisipan dalam penelitian ini memiliki keterbukaan diri yang lebih rendah pada hubungan persahabatan berbeda jenis kelamin daripada hubungan yang lain.

Hasil pengujian hipotesis ketiga, menunjukkan bahwa ada interaksi antara konteks budaya dengan jenis hubungan dalam mempengaruhi keterbukaan diri. Nilai signifikansi yang diperoleh sebesar 0,022 $<0,05$, mengartikan bahwa H03 ditolak sehingga ada interaksi antara konteks budaya dengan jenis kelamin dalam hal tingkat keterbukaan diri atau membuktikan adanya perbedaan efek konteks budaya dalam jenis hubungan yang berbeda.

Tabel 4 menunjukkan perbandingan rata-rata keterbukaan diri dari jenis hubungan pada kelompok sampel masing-masing. Dapat dilihat bahwa hubungan romantis memiliki nilai keterbukaan diri yang paling tinggi pada budaya romantik pertemanan romantis jenis kelamin memiliki nilai paling tinggi pada budaya Batak, sedangkan pertemanan berbeda jenis kelamin menjadi yang paling rendah di setiap kelompok budaya. Dapat dilihat pula selisih perbedaan nilai keterbukaan diri pada masing-masing jenis hubungan pada budaya Jawa lebih besar daripada budaya Batak. Hasil tersebut dapat dilihat pula pada bagan 4.1. yang menunjukkan perbandingan tingkat keterbukaan diri pada masing-masing kelompok subyek.

Tabel 4

Mean Budaya * Jenis Hubungan

Dependent Variable: Self Disclosure
\begin{tabular}{|ll|r|r|r|r|}
\hline \multirow{4}{*}{ Budaya } & Jenis Hubungan & & & \multicolumn{2}{|c|}{$95 \%$ Confidence Interval } \\
\cline { 5 - 6 } Batak & Rean & Std. Error & Lower Bound & Upper Bound \\
& Same-sex Friendship & 58.900 & 2.461 & 54.043 & 63.757 \\
& Cross-sex Frienship & 50.733 & 2.461 & 45.877 & 55.590 \\
\hline \multirow{2}{*}{ Jawa } & Romantic Relationship & 58.900 & 2.461 & 54.043 & 63.757 \\
& Same-sex Friendship & 52.000 & 2.461 & 47.143 & 56.857 \\
& Cross-sex Frienship & 38.133 & 2.461 & 33.277 & 42.990 \\
\hline
\end{tabular}

Dari hasil analisis, ditemukan pada budaya Jawa, tingkat keterbukaan dalam hubungan romantik lebih tinggi daripada hubungan persahabatan, tetapi pada budaya Batak, tingkat keterbukaan paling tinggi ditemukan pada hubungan persahabatan berjenis kelamin sama. Hasil ini mendukung hasil penelitian Cramer (1990) bahwa tidak selalu pengungkapan diri paling tinggi terjadi pada hubungan romantik, tetapi berbeda dengan penelitian Tschann (1988) yang menunjukkan hasil bahwa keterbukaan diri paling tinggi ditemukan pada hubungan romantik. Inkonsistensi ini mungkin dikarenakan masing-masing budaya memandang secara 
berbeda terhadap sifat hubungan masing-masing, sehingga topik yang diungkapkan oleh seseorang kepada pasangannya menjadi berbeda dengan topik yang diungkapkan kepada sahabatnya.

Hasil analisis dan temuan-temuan kunci tersebut telah merujukkan hasil yang dapat disimpulkan yaitu ada perbedaan tingkat keterbukaan diri antara konteks budaya yang berbeda, dan antara jenis hubungan yang berbeda. Pembuktian perbedaan tersebut membenarkan hipotesis teoretis bahwa keterbukaan dipengaruhi oleh konteks budaya dan juga jenis hubungan.

\section{KESIMPULAN}

Terdapat perbedaan tingkat keterbukaan diri yang signifikan berdasarkan konteks budaya dan jenis hubungan. Hasil tersebut diperoleh berdasarkan survey terhadap mahasiswa Universitas XYZ yang tengah memiliki hubungan romantis, dan berlatar belakang budaya Jawa sebagai representasi budaya konteks tinggi atau budaya Batak sebagai representasi budaya konteks rendah.

Adanya perbedaan tingkat keterbukaan diri yang signifikan berdasarkan jenis hubungan dan konteks budaya menunjukkan hubungan kausal antara keterbukaan diri dengan konteks budaya dan jenis hubungan. Melalui penelitian ini juga ditemukan interaksi yang signifikan antara jenis hubungan dan konteks budaya dalam mempengaruhi tingkat keterbukaan diri yang menunjukkan ada perbedaan dampak jenis hubungan terhadap keterbukaan diri pada konteks budaya yang berbeda, atau perbedaan dampak konteks budaya terhadap keterbukaan diri pada jenis hubungan yang berbeda.

Kesediaan setiap orang untuk mengungkapkan informasi mengenai dirinya, berbeda antara satu dengan lainnya. Banyak hal yang menyebabkan perbedaan tersebut. Penelitian ini menunjukkan latar belakang budaya dan jenis hubungan menjadi beberapa dari banyaknya penyebab perbedaan kesediaan pengungkapan diri tersebut.

Keterbukaan diri memang bersifat resiprokal. Keterbukaan diri dari seseorang akan membawa keterbukaan balasan dari orang lain. Namun, batasan keterbukaan setiap orang berbeda-beda, dibuktikan melalui penelitian ini. Oleh sebab itu, dalam berkomunikasi dengan orang lain, menjadi lebih baik untuk menjaga ekspektasi terhadap perilaku keterbukaan resiprokal yang diterima. Menjadi lebih baik pula apabila tidak mengharapkan perilaku keterbukaan balasan pada tingkatan yang sama dengan keterbukaan diri yang diberikan, bertolak pada pemahaman dari hasil penelitian ini bahwa kesediaan setiap orang untuk membuka diri kepada orang lain, berbeda satu dengan yang lain.

\section{Daftar Pustaka}

Babbie, Earl. 2010. The Practice of Social Research. USA: Wadsworth.

Bleske-Rechek, A. L. \& Buss, D. M. (2001) Opposite-sex friendship: Sex and similarities in initiation, selection, and dissolution. Personality and Social Psychology Bulletin 27:1310-23.

Chan, Darius K.S., Grand H.L. Cheng. (2004). A Comparison of Offline and Online Friendship Qualities at Different Stages of Relationship Development. Journal of Personal and Social Relationship, 305-320.

Eman, K.K.I.F. 2004. Perbedaan Profil Kepribadian Suku Jawa dan Suku Batak Berdasarkan Five Factor of Personality. Skripsi Sarjana Psikologi pada Unika Atma Jaya.

Griffin, Em. 2012. A First Look at Communication Theory. New York: Mc Grawhill.

Hatfield, E., Pillemer, Jane. T, dkk. (2008). Passionate and companionate love in Newlywed and Longterm Marriages. Interpersona, 2, 35-64.

Jourard, Sidney M. dan Paul Lasakow. (1958). Some Factors in Self-Disclosure. Journal of Abnormal and Social Psychology, 56, 91-98.

Kito, Mie. (2005). Self-Disclosure in Romantic Relationships and Friendships Among American and Japanese College Students. The Journal of Social Psychology, 145, 127-140.

Littlejohn, Stephen W. dan Karen A. Foss. 2009. Theories of Human Communication. USA: Thompson Wadsworth. 
Matsushima, Rumi, Kunio Shiomi,. (2002). Self-disclosure and friendship in junior high school students. Social Behavior and Personality, 30, 515.

Neumann, W.Laurence. 2007. Basics of Social Research: Qualitative and Quantitative Approach. Boston: Pearson Education.

Pratiwi, Diah Aryani. (2015). Perbedaan Pengungkapan Diri antara Mahasiswa Suku Jawa dengan Suku Batak Melalui Twitter. Malang: Universitas Brawijaya.

Samovar, Larry A., Richard E. Porter, Edwin R. McDaniel. 2010. Komunikasi Lintas Budaya: Communication Between Cultures. Jakarta: Salemba Humanika.

Tang N., Bensman L. \& Hatfield E.. (2013). Culture and sexual self-disclosure inintimate relationships. Interpersona:An International Journal on Personal Relationships 7, 227-245.

Wood, Julia T.. 2007. Interpersonal Communication: Everyday Encounters 5th edition. USA: Thomson Wadsworth.

Wood, Julia T.. 2008. Communication Mossaics: An Introduction to the Field of Communication, 5th edition. USA: Thomson Wadsworth. 